\title{
Risk Disclosure dan Kinerja Perusahaan dengan Corporate governance sebagai Variabel Moderasi
}

\author{
Amalia Restika ${ }^{1}$ \\ Fakultas Ekonomi dan Bisnis \\ Universitas Trilogi, Indonesia
}

\author{
Anies Lastiati ${ }^{2}$ \\ Fakultas Ekonomi dan Bisnis \\ Universitas Trilogi, Indonesia
}

\begin{abstract}
Surel : amaliarestika@gmail.com
ABSTRAK

Tujuan dari penelitian ini adalah untuk mengetahui pengaruh dari risk disclosure terhadap kinerja perusahaan. Lebih jauh, penelitian ini juga menguji apakah tata kelola (jumlah dewan komisaris, komisaris independen, dan komite audit) mengubah intensitas pengaruh risk disclosure terhadap kinerja perusahaan. Sumber data penelitian adalah perusahaan manufaktur yang terdaftar dalam Bursa Efek Indonesia pada tahun 2017 - 2018. Total sampel sebesar 174 perusahaan, dengan metode purposive sampling. Teknik analisis menggunakan pengujian confimatory analysis factor (CFA), uji asumsi klasik dan uji regresi linear berganda. Hasil penelitian menunjukkan bahwa risk disclosure berpengaruh positif terhadap kinerja. Jumlah dewan komisaris dan komisaris independen memperkuat hubungan risk disclosure dengan kinerja perusahaan, namun komite audit tidak mempengaruhi hubungan risk disclosure terhadap kinerja perusahaan.
\end{abstract}

Kata Kunci: Corporate Governance; Kinerja Perusahaan; Risk Disclosure.

\section{Risk Disclosure And Company Performance With Corporate Governance As Moderation Variables}$$
\text { ABSTRACT }
$$

This study aims to examine the effect of risk disclosure to firm performance. It further examines whether corporate governance (Board of commisioner, independent comminisioner, andgaudit committee) moderates the relationship between risk disclosure and firm performance. The sources of this study were manufacturing companies listed on Indonesia Stock Exchange in 2017 - 2018. The number of samples was 174 companies, with a purposive sampling method. The technique of analysis uses confimatory analysis factor (CFA), classic assumption tst, and multiple linear regression test. The results show that risk disclosure has a positive influence on the firm performance. Furthermore results shows that board of commissioner and independent commisioner strengthen the relationship between risk disclosure and firm performance. This role, however is not found in the corporation's audit committee. The committee does not have any impact whatsoever to the relationship between risk disclosure and coporates' performance.

Keywords: Corporate Governance; Firm Performance; Risk Disclosure.
\end{abstract}

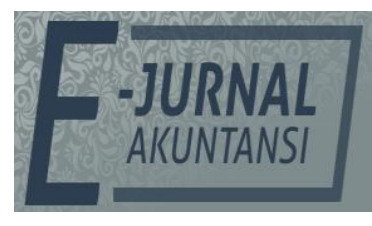

e-ISSN 2302-8556

Vol. 31 No. 5

Denpasar, Mei 2021

Hal. 1154-1168

DOI:

10.24843/EJA.2021.v31.i05.p07

PENGUTIPAN:

Restika, A., \& Lastiati, A.

(2021). Risk Disclosure dan

Kinerja Perusahaan dengan

Corporate governance sebagai Variabel Moderasi. E-Jurnal

Akuntansi, 31(5), 1154-1168

RIWAYAT ARTIKEL:

Artikel Masuk: 17 Februari 2021 Artikel Diterima: 24 Mei 2021

Artikel dapat diakses : https://ojs.unud.ac.id/index.php/Akuntansi/index 


\section{PENDAHULUAN}

Risiko dapat didefinisikan sebagai bentuk ketidakpastian (Darmawi, 2014). Risiko dalam suatu perusahaan tidak dapat dihilangkan, informasi risiko perusahaan digunakan sebagai alat pengambil keputusan (Saufanny \& Khomsatun, 2017). Pengungkapan risiko merupakan informasi dari manajemen tercantum dalam laporan tahunan perusahaan yang dikirimkan kepada stakeholders untuk membantu dan mempermudah dalam pengambilan keputusan. Menurut United Nations Conference on Trade and Development (UNCTAD) tahun 2007 pengungkapan risiko dalam laporan tahunan dibagi menjadi dua yaitu mandatory disclosure (pengungkapan wajib) dan voluntary disclosure (pengungkapan sukarela).

Contoh kasus di Indonesia yang menimbulkan dampak pada risiko ruskanya lingkungan dilakukan oleh PT Pindo Deli pulp dan Peper Mills pada tahun 2015 disebabkan karena pembuangan limbah cair diduga mengandung racun dan berbau busuk yang dibuang di Sungai Cibeet (Luthfiana, 2015). Kasus serupa juga dilakukan oleh PT Newmont Minahasa raya menyangkut pencemaran Teluk Buyat dengan membuang limbah yang mengdung merkuri secara langsung.

Pentingnya pengelolaan risiko mendorong badan regulator membuat peraturan untuk mewajibkan perusahaan melaporkan risiko perusahaan sesuai dengan PSAK No. 60 (revisi 2016) tentang instrumen keuangan. Regulasi mengenai manajemen risiko tercantum di dalam Keputusan Ketua Bapepam Nomor: KEP-431/BL/2012. Meskipun sudah diatur dalam regulasi namun pengungkapan risiko antara satu dengan lain dapat berbeda tergantung dengan jenis usaha yang dijalankan (Abdullah, 2018). Risiko timbul akibat adanya kondisi ketidakpastian, dan bisa menimbulkan kerugian keuangan jika tidak dikelolah sedini mungkin, namun jika pengelolaan risiko dilakukan dengan baik memiliki dampak positif dalam memaksimalkan nilai kinerja perusahaan (Arifah \& Wirajaya, 2018). Menurut Attar, et al., (2014) Return On Asset (ROA) adalah rasio pengukur kemampuan manajemen dalam memperoleh keuntungan bersih dengan menggunakan aset perusahaan. Menurut Gisbon, (2009) ROA dapat menggambarkan kemampuan perusahaan untuk memanfaatkan aset menjadi laba dengan membandingkan asset dengan laba. Sedangkan Kasmir (2012) berpendapat bahwa return on equity (ROE) adalah rasio yang dapat digunakan sebagai alat ukur laba bersih setelah pajak dengan modal sendiri. Rasio ini menunjukan efesiensi penggunaaan modal kerja. Menurut Fraser \& Ormiston, 2012 dalam Sakti, (2017) menyatakan kinerja keuangan dapat diukur menggunakan ROA dapat memperhitungkan bagaimana perusahaan mengelola asset yang dimiliki, serta ROE dapat memperhitungkan seberapa besar perusahaan mengelola ekuitas yang dimiliki, sedangkan profit margin dapat memperhitungkan efisiensi manajemen dalam mengelolah penjualan, menetapkan harga produk, dan mengendalikan biaya dengan baik.

Penelitian yang telah dilakukan oleh Albiatar (2015) berfokus pada voluntary disclosure dalam laporan tahunan negara Yordania, hasil dari penelitian memiliki tingkat pengungkapan suakrela cenderung rendah hanya sebesar 38,6persen. Pengukuran statistik menunjukan hubungan positif antara pengungkpan sukarela dengan ukuran dan umur perusahaan, serta likuiditas. 
Tata kelola perusahaan berpengaruh positif terhadap pengungkapan sukarela. Penelitian yang telah dilakukan oleh Amran, et al., (2009) menunjukan pengungkapan risiko pada negara Malaysia masih dalam tahap pertumbuhan, dihitung menggunakan total kalimat yang diungkapan, hasil menunjukan rata rata pengungkapan risiko hanya sebanyak 20 kalimat. Penelitian yang dilakukan oleh Nahar et al., (2016) terkait hubungan tata kelola risiko yang digambarkan dengan pengungkapan risiko, jumlah komite risiko, dan manajemen risiko memiliki pengaruh positif terhadap kinerja bank, manajemen risiko dapat meningkatkan perencanaan dan pengawasan risiko.

Sistem tata kelola perusahaan memegang peranan penting dalam pengelolaan risiko dan peningkatan kinerja perusahaan. Menurut Velnampy, (2013) dalam Onasis \& Robin (2016) corporate governance merupakan sistem yang terdiri dari sekumpulan mekanisma, prosedur, serta struktur yang dengan tujuan mengelola perusahaan berlandaskan prinsippakuntabilitas yang dapat memaksimalkan nilai perusahaan jangka panjang. Kasus yang menimpa PT Tiga Pilar Sejahtera Food Tbk merupakan salah contoh pentingnya tata kelola dalam perusahaan.

Penelitian penerapan tata kelola dilakukan oleh Iswara (2014) menyatakan bahwa terdapat pengaruh positif antara tata kelola dengan kinerja pasar perusahaan yang diukur menggunakan Tobin's $Q$. Sejalan dengan penelitian Puteri (2013) menyatakan bahwa komisaris independen, komite manajemen risiko berpengaruh positif dalam memaksimalkan kinerja perusahaan. Penelitian yang dilakukan oleh Aryanto \& Setyorini (2019) menyatakan bahwa komite audit berpenagtuh positif terhadap nilai perusahaan, peran komite audit menghambat perilaku manajemen untuk memanipulasi laporan keuangan sehingga manajemen laba dapat ditekan. Hasil penelitian Siek (2015) menyatakan dewan komisaris independen tidak memiliki pengaruh terhadap nilai perusahan hal tersebut dapat terjadi karena komisaris independen hanya dijadikan syarat minimal jumlah komisaris yang ditetapkan oleh BEI. Permasalah yang dapat disimpulkan dari latar belakang penelitian, apakah pengungkapan risiko berpengaruh terhadap kinerja perusahaan pada sektor manufaktur terdaftar dalam BEI, Apakah corporate governance mempengaruhi pengaruh terhadap antara pengungkapan risiko dengan kinerja perusahaan.

Teori sinyal yang diungkapan oleh Spence (1973) dalam Godfrey et al., (2010) menjelaskan bahwa pihak pengirim (pemilik informasi) mengirimkan suatau isyarat berupa informasi yang menggambarkan kondiri suatu perusahaan yang bermanfaat bagi pihak penerima. Teori sinyal menjelaskan tentang penekanan pada pentingnya pemberian informasi yang dikeluarkan perusahaan kepada pihak di luar perusahaan melalui sinyal atau tanda dalam laporan tahunan (Karewur, 2016). Signaling mencerminkan keandalan informasi yang disampaikan agent kepada principal melalui pengungkapan risiko dalam laporan tahunan pada praktik usahanya, para manajer membutuhkan pihak - pihak dari luar manajemen perusahaan, pihak tersebut meliputi investor, kreditor, pemasok, serta pelanggan.

Teori Keagenan merupakan sebuah kontrak antara satu atau lebih (principal) yang mengikutsertakan orang lain atau agent untuk memberikan pelayanan dalam mendelegasikan pengambilan keputusan kepada agent 
tersebut Jensen \& Meckling, 1976 dalam Godfey, et al., (2010). Agency Theory diartikan sebagai hubungan antara individu pemilik usaha atau pemegang saham dan para manajer. Teori ini menjelaskan manajer (agent) adalah pihak yang mengelolah perusahaannya dalam memaksimalkan keuntungan serta memilih, memutuskan, dan bertanggung jawab bagi kepentingan pemilik atau pemegang saham (principal) (Lo, 2012). Agency Theory dapat digunakan sebagai dasar pengungkapan risiko. Manajer adalah pihak yang memahami kondisi perusahaan dan memiliki informasi lebih dibandingkan pemegang saham. Principal dapat memperhitungkan informasi yang didapatkan melalui agen mengenai keadaan perusahaan dimasa mendatang. Pengungkapan risiko dibutuhkan oleh principal dalam mempertimbangkan keputusan dan menghindari konflik kepentingan antara principal dan agent.

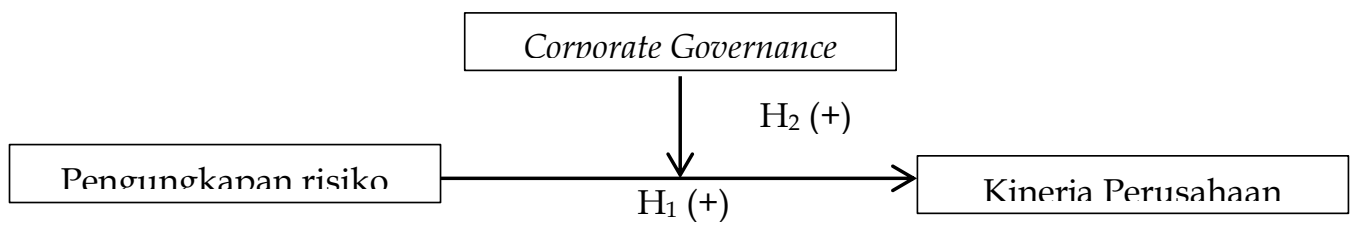

\section{Gambar 1. Model Penelitian}

Sumber: Data Penelitian, 2019

Menurut Salomon (2000) dalam Utami \& Ratmono (2018) Pengungkapan informasi perusahaan bertujuan untuk menyelasarkan kepentingan stakeholder dan manajemen, maka keterbukaan informasi dapat mengurangi biaya agensi dan peningkatan kinerja perusahaan. Profitabilitas merupakan tolak ukur kinerja perusahaan. Sedangkan menurut Saskara \& Bidiasih (2018) Perusahaan dengan manajemen risiko lebih luas cenderung menghasilkan profitabilitas lebih tinggi, dikarenakan perusahaan dapat mengelola risiko dengan baik dan meningkatkan kepercayaan stakeholder terhadap siklus hidup perusahaan. Menurut Linsley \& Shrives (2000) perusahaan perlu memiliki kemampuan dalam manajemen risiko karena memiliki dampak signifikan pada keuangan perusahaan. Pengelolaan risiko mendiring perusahaan dalam menilai risiko dari tingkat rendah hingga tertinggi, sehingga semakin luas pengungkapan yang diberikan perusahaan dalam melaporkan infromasi, maka reputasi akan meningkat sehingga meningkatkan nilai perusahaan serta kekuatan dalam bertahan. Maka dapat disimpulkan sebagai berikut.

$\mathrm{H}_{1}$ : Semakin luas pengungkapan risiko semakin tinggi nilai kinerja perusahaan.

Coporate Governance merupaka sistem yang bertugas dalam mengatur dan mengendalikan perusahaan, yang diharapkan dapat meningkatkan pengawasan terhadap pelaporan risiko serta meningkatkan nilai kinerja perusahaan (Sianipar et al., 2018). Dewan komisaris, komisaris independen, dan komite audit memiliki fungsi dalam pengawasan manajemen dalam menjamin tingkat keefektifan pengawasan terhadap kinerja perusahaan dalam mencegah adanya kecenderungan manajer melakukan kecurangan (Pamudji \& Trihartati, 2010). Penelitian oleh Brown \& Cayrol (2004) perusahaan yang memiliki jajaran eksekutif dengan kinerja baik maka akan meningkatkan kinerja perusahaan. Dapat disimpulkan hipotesis dari penelitian ini adalah sebagai berikut.

$\mathrm{H}_{2}$ : Corporate governance akan memperkuat pengaruh pengungkapan risiko terhadap kinerja perusahaan. 


\section{METODE PENELITIAN}

Metode pengambilan data adalah purposive sampling method yaitu merupakan tipe pemilihan sampel tidak acak atau sesuai dengan kriterias bertujuan mendapatkan sampel yang representative terkait informasi yang dibutuhkan. Sampel yang digunakan pada penelitian ini merupakan seluruh perusahaan manufaktur yang terdaftar dalam Bursa Efek Indonesia (BEI) dalam periode 2017-2018 didasarkan pada pertimbangan bahwa data yang digunakan up to date sehingga menggambarkan perusahaan terkini. Terdiri dari berbagai sub sektor industri, total perusahaan manufaktur yang listing pada 2017 sebesar 159 perusahaan dan pada tahun 2018 sebesar 178 perusahaan, sehingga total perusahaan manufaktur tahun 2017 - 2018 sebesar 337 perusahaan.

Penelitian ini menggabungkan ketiga variabel menjadi satu corporate governance index dengan menggunakan confirmatory analysis factor (CFA) dengan tujuan menggabungkan dan mereduksi variabel sehingga dapat mewakili konstruk yang terbentuk dalam menganalisis model penelitian. Mengikuti penelitian sebelumnya yang telah dilakukan oleh Kocmanova \& Simberova (2012) menggabungkan beberapa variabel menjadi satu faktor. Kinerja perusahaan dipilih menjadi variabel dependen dalam penelitian ini menggunakan proksi Return on Asset (ROA), Return on Equity (ROE).

$\mathrm{ROA}=$ Laba bersih / total asset.

ROE $=$ Laba bersih / total equity

\section{Tabel 1. Daftar item pengungkapan risiko}

\begin{tabular}{|c|c|c|}
\hline No & Risk Disclosure Index & Sumber \\
\hline 1 & Risiko yang timbul oleh perubahan iklim & GRI $201-2$ \\
\hline 2 & Dampak investasi infrastruktur dan dukungan layanan & GRI $203-1$ \\
\hline 3 & $\begin{array}{l}\text { Dampak yang timbul dari ekonomi tidak langsung } \\
\text { (indirect economic) }\end{array}$ & GRI $203-2$ \\
\hline 4 & Risiko terkait korupsi & GRI $205-1$ \\
\hline 5 & Risiko terkait perpajakan & GRI 207 - 2 \\
\hline 6 & Dampak pada keanekaragaman hayati & GRI $304-2$ \\
\hline 7 & Dampak terkait limbah & GRI $306-1$ \\
\hline 8 & Dampak negatif lingkungan & GRI 308 - 2 \\
\hline 9 & $\begin{array}{l}\text { Risiko terkait kesehatan dan keselamatan kerja } \\
\text { karyawan dan pekerja non karyawan }\end{array}$ & GRI $403-2$ \\
\hline 10 & $\begin{array}{l}\text { Risiko terkait operasi dan pemasok terhadap insiden } \\
\text { pekerja anak }\end{array}$ & GRI $408-1$ \\
\hline 11 & $\begin{array}{l}\text { Risiko terkait operasi dan pemasok terhadap insiden } \\
\text { kerja paksa atau wajib kerja }\end{array}$ & GRI 409 - 1 \\
\hline 12 & Dampak negatif sosial & GRI $414-2$ \\
\hline
\end{tabular}

Sumber: Data Penelitian, 2020

Pengungkapan risiko yang dianalisis menggunakan metode content analysis. Sejalan dengan penelitian (Linsley \& Shives, 2014), (Abraham \& Cox, 2007), (Syaifukman \& Laksito, 2016) (Yunifa \& Juliarto, 2017), dan (Faisal \& Ghozali, 2018). Metode ini digunakan juga dalam penelitian Amran, Bin, \& Hassan, (2009) yang berfokus pada jumlah pengungkapan risiko bukan pada kualitas pengungkapan risiko, namun dapat menghasilkan kesimpulan yang valid dari sebuah konteks kalimat. 
Setiap item pengungkapan yang tercantum dalammlaporan tahunan perusahaan diberikan skor satu (1) dan nilai nol (0) jika tidak diungkapkan dalam laporan tahunan, dengan indeks skor maksimal 12. Selanjutnya setiap skor akan dijumlahkan untuk memperoleh keseluruhan skor untuk setiap perusahaan. Pengukuran variabel menggunakan formula Risk Disclosure Index (RDI) yang telah di lakukan oleh (Muslih \& Mulyaningtyas, 2019), (Bae et al., 2018) sebagai berikut.

$R D I=\frac{\text { Jumlah skor RDI yang di ungkapkan }}{\text { Jumlah maksimum item yang diungkapkan }(=12)} \mathrm{X}$

100persen.

Variabel moderasi yang digunakan meliputi kontrol internal perusahaan. Pengukuran dewan komisaris dilakukan berdasarkan jumlah anggota dewan komisaris yang tercantum dalam laporan tahunan perusahaan. Proporsi komisaris independen diukur dengan jumlah dewan komisaris independen dibagi keseluruhan anggota dewan komisaris. Proporsi dewan komisaris di ukur dengan membagi jumlah komite audit berlatar belakang keuangan dan akuntansi dengan jumlah anggota komite audit.

Variabel kontrol teridiri dari umur perusaahaan dan ukuran perusahaan. Umur perusahaan merupakan jumlah rentang waktu lamanya perusahaan berdiri dan beroperasi. Penelitian sebelumnya dilakukan oleh (Saemargani \& Mustikawati, 2015), (Arman, 2012), (Susilatri, et al., 2011), (Dewinta \& Setiawan, 2016), dan (Claudio \& Urs, 2010). Ukuran perusahaan penelitian ini ukur berdasarkan total aset yang dimiliki perusahaan dengan logaritma natural (Ln) dari tetap aktiva, dikarenakan total aktiva setiap perusahaan berbeda dan memiliki selisih yang besar sehingga dapat menimbulkan nilai ekstrim. Penelitian sebelumnya oleh (Ruwita, 2012), (Atmaja, et al., 2015), (Wardhany, et al., 2019) dan (Umum \& Hartono 2019).

AGE_FIRM = Tahun tutup buku perusahaan - Tahun perusahaan terdaftar di

$$
\text { BEI. }
$$

Size $=$ Ln (Total assets)

Dalam analisa data dari penelitian ini digunakan regresi penelitian dapat digambarkan sebagai berikut

PERFORMANCE $=\propto+\beta 1$ RDI $+\beta 1$ AGE_FIRM $+\beta 2$ SIZE $+\varepsilon$

PERFORMANCE $=\propto+\beta 1$ RDI $+\beta 2$ RDI.DK $+\beta 3$ RDI.KI $+\beta 4$ RDI.KA $+\beta 5$ Age + $\beta 6 \mathrm{SIZE}+\varepsilon$

\section{HASIL DAN PEMBAHASAN}

Berdasarkan hasil analisis CFA dengan bantuan STATA 15, maka dapat dibuat analisis tabel sebagai berikut.

Tabel 2. Hasil Pengujian Kaiser Mayer Olkin (KMO) dan Bartlett Test Of Sphericity

\begin{tabular}{lc}
\hline Bartlett test of sphericity & \\
\hline Chi-square & 205,455 \\
Degress of freedom & 1 \\
$P$-value & 0,000 \\
Kaiser-Mayer-Olkin Measure of Sampling Adequace \\
KMO & 0,500 \\
\hline
\end{tabular}

Sumber: Data Penelitian, 2020 
Variabel dependen terdiri dari ROA dan ROE dengan nilai KMO - MSA sebesar 0.500 dan nilai Bartlett test sebesar 0.000, artinya analisis dapat dilanjutkan karena telah memenuhi persyaratan dalam pembentukan faktor.

Tabel 3. Hasil Pengujian Principal Component Analysis

\begin{tabular}{lllll}
\hline Factor & Eigenvalue & Difference & Proportion & Cumulative \\
\hline Factor 1 & 1,8356 & 1,6712 & 0,9178 & 0,9178 \\
Factor 2 & 0,1164 & & 0,0822 & 1,0000 \\
Number obs & 174 & & & \\
Prob $>$ chi 2 & 0,000 & & & \\
Factor Loadings & & Factor & Uniqness & \\
Variabel & & 0,9580 & 0,0822 & \\
ROA & & 0,9580 & 0,0822 & \\
ROE & &
\end{tabular}

Sumber: Data Penelitian, 2020

Berdasarkan pengujian principal component factor total variance pada bagian initial eigen values memiliki 1 (satu) faktor yang dapat terbentuk dari 2 variabel, syarat menjadi sebuah faktor yaitu memiliki nilai eigen value lebih besar dari 1 . Nilai eigen value pada component 1 yaitu sebesar 1,8355 atau lebih besar dari 1, maka faktor mampu menjelaskan 91,78 persen variasi.

Tabel 4. Hasil Uji Varimax Rotation

\begin{tabular}{lcccc}
\hline Factor & Variance & Difference & Proportion & Cumulative \\
\hline Factor 1 & 1,8356 &. & 0,9178 & 0,9178 \\
Rotate factor loadings & & & \\
Variabel & Factor 1 & Uniqueness & \\
ROA & 0,9580 & 0,0822 & \\
ROE & 0,9580 & 0,0822 &
\end{tabular}

Factor rotation matrix

Factor1

Factor1 1,0000

Sumber: Data Penelitian, 2020

Hasil pengujian rotate varimax digunakan untuk memastikan variabel yang termasuk dalam kelompok faktor, maka dapat menentukan nilai korelasi terbesar antar variabel dengan faktor yang terbentuk. Dari hasil pengujian rotate varimax variabel return on assets memiliki nilai korelasi dengan faktor 1 sebesar 0.9580, variabel return on equity dengan nilai korelasi yaitu 0,9580. Untuk menggabungkan variabel asli pada satu faktor maka, variabel digabungkan menggunakan summated scale, tujuannya menciptakan ukuran tunggal dari multi aspek sebuah konstruk.

Nilai adjusted R-squares pada variabel sebesar 0.1023 atau 10.23persen, memiliki arti bahwa variabel independen yaitu risk disclosure serta variabel kontrol umur perusahaan pada menjelaskan variabel dependen sebesar 10.23persen, sisanya 89,77 persen dijelaskan oleh variabel diluar penelitian. Hasil uji global menunjukan bahwa variabel independen dan variabel kontrol berpengaruh secaran simultan terhadap variabel dependen dengan nilai prob > chi2 0,0006, lebih kecil dari pada 0,05.

Hasil pengujian individu pada variabel RDI menunjukkan nilai signifikansi sebesar 0,000 $<0,01$ dengan nilai koefisien 0,123, maka dapat diketahui bahwa variabel RDI memiliki hubungan positif dan berpengaruh 
signifikan terhadap Performance. Pengungkapan risiko dapat memberikan dampak positif bagi perusahaan, masyarakat dan lingkungan karena perusahaan memperhitungkan dampak yang akan dihasilkan dari jalannya operasional perusahaan. Pelaporan risiko merupakan alat perlindungan diri dan sebagai jaminan jika terjadi kerusakan yang dapat menyebabkan kerugian di masa mendatang. Pengungkapan risiko secara detail, lengkap, dan akurat dapat menunjukan kemampuan perusahaan dalam mengelola risikonya, sehingga semakin baik perusahaan melakukan pengungkapan risiko akan memberikan feedback yang baik terhadap kinerja perusahaan (Supriyadi \& Setyorini, 2020).

Tabel 5. Hasil Analisis Regresi Linear

\begin{tabular}{lllll}
\hline Variabel & \multirow{2}{*}{ Dugaan } & \multicolumn{3}{c}{ Performance } \\
\cline { 3 - 5 } & & Coef & p-value & \\
\hline RDI & + & 0,123 & $0,000^{* * *}$ & \\
AGE_FIRM & + & $-0,005$ & 0,263 & \\
SIZE & + & 0,003 & 0,283 & \\
_cons & & $-0,038$ & 0,386 & \\
R & & &
\end{tabular}

$\begin{array}{lr}\text { R-Sq } & 0,1023 \\ \text { Prob>Chi2 } & 0,0006\end{array}$

Keterangan: ${ }^{*}, * *, * * *$ signifikansi pada alpha 10persen, 5 persen, 1 persen

PERFORMANCE terdiri dari ROA dan ROE; RDI (risk disclosure indeks) dihitung dengan membagi total pengungkapan perusahaan dengan item pengukuran; AGE_FIRM merupakan tahun tutup buku perusahaan dikurangi tahun perusahaan terdaftar di BEI; SIZE diukur menggunakan logaritma natural total asset

Sumber: Data Penelitian, 2020

Sinyal positif yang dihasilkan dari keterbukaan pengungkapan risiko dapat menguatkan citra dan reputasi perusahaan dimata pelanggan sehingga meningkatkan loyalitas pelanggan, pada akhirnya konsumen akan menyalurkan dananya lewat pembelian produk dan jasa perusahaan sehingga meningkatkan profitabilitas perusahaan (Sari, Handayani, \& Nuzula, 2016). Sejalan dengan penelitian oleh Abdullah (2018), mengungkapkan perusahaan dengan tingkat profitabilitas yang tinggi maka dapat mengelola risiko yang akan terjadi dengan baik hal tersebut akan menjadi sinyal yang baik bagi para investor dan pengguna laporan tahunan. Nahan, Jub \& Azim (2016) mengemukaan terdapat terdapat hubungan yang positif dan pengaruh signifikan antara luas pengungkapan risiko dengan kinerja perusahaan, pengungkapan risiko secara luas dapat mengurangi asimetri informasi, meningkatkan kepercayaan shareholder, dan mengurangi adanya ketidakpastian yang akan terjadi pada waktu mendatang

Variabel kontrol yaitu AGE_FIRM menunjukkan nilai koefisien sebesar 0,005 dengan nilai signifikansi sebesar 0.263 , artinya umur perusahaan tidak berpengaruh terhadap variabel kinerja perusahaan. Sejalan dengan penelitian Hariyanto \& Juniarti (2014) dalam Novyany \& Turangan (2018) yang menyatakan bahwa umur perusahaan yang telah lama berdiri maka perusahaan semakin tidak lebih profit dibandingkan dengan perusahaan yang baru berdiri, dikarenakan adanya penurunan laba yang disebabkan bertambahnya pesaing dan munculnya perusahaan baru. Variabel SIZE menunjukan nilai koefisien sebesar 0,003 dengan signifikansissebesar 0,283, menunjukan bahwa tidak ada pengaruh antara ukuran perusahaan dengan kinerja perusahaan. Penelitian ini sejalan dengan penelitian yang dilakukan oleh (Irma, 2019), yang menyatakan 
bahwa ukuran total asset bukan menjadi patokan perusahaan tersebut mendapatkan tingkat persentase kinerja perusahaan yang kecil. Terdapat banyak faktor yang perlu dipertimbangkan, termasuk mengelola aset yang dimiliki dengan efisien agar mendapat keuntungan maksimal.

Tabel 6. Hasil Regresi Risk Disclosure Index dan Kinerja Perusahaan dengan Moderasi Corporate governance

\begin{tabular}{llll}
\hline \multicolumn{1}{c}{ Variabel } & Dugaan & \multicolumn{1}{c}{ Performance } \\
\cline { 3 - 4 } & & Coef & -value \\
\hline RDI & + & $-0,056$ & $0,053^{*}$ \\
DK & & $-0,012$ & $0,041^{* *}$ \\
KI & $-0,198$ & $0,021^{* *}$ \\
KA & & 0,0135 & 0,401 \\
RDI.DK & + & 0,039 & $0,060^{*}$ \\
RDI.KI & + & 0,651 & $0,010^{* *}$ \\
RDI.KA & + & 0,022 & 0,444 \\
AGE_FIRM & + & $-0,006$ & 0,224 \\
SIZE & + & 0,002 & 0,351 \\
cons & & 0,109 & 0,257 \\
R-Sq & & & 0,1155 \\
Prob > Chi2 & & & 0,0015
\end{tabular}

Keterangan: ${ }^{*}, * * * * *$ signifikansippada alpha 10persen, 5 persen, 1 persen

PERFORMANCE terdiri dari ROA dan ROE. RDI (risk disclosure indeks) diukur dengan membagi total pengungkapan perusahaan dengan item pengukuran; AGE_FIRM merupakan tahun tutup buku perusahaan dikurangi tahun perusahaan terdaftar di BEI; SIZE diukur menggunakan logaritma natural total asset; DK diukur dengan jumlah keseluruhan dewan komisaris; KI diukur dengan proporsi komite independen; KA diukurldengan total keseluruhan komite audit dengan latar belakang pendidikan keuangan dibagi jumlah keseluruhan komite audit

Sumber: Data Penelitian, 2020

Nilai adjusted $R$-Square adalah sebesar 0,1155 atau 11,55 persen, memiliki arti bahwa variabel independen yaitu risk disclosure, variabel moderasi yang terdiri dari dewan komisaris, komisaris independen, dan komite audit, serta variabel kontrol yang terdiri dari umur perusahaan dan ukuran perusahaan dapat menjelaskan variabel dependen yaitu kinerja perusahaan sebesar 11,55 persen, sisanya 88,45 persen dijelaskan oleh variabel di luar penelitian. Hasil uji global menunjukan nilai Prob $>$ Chi2 sebesar 0,0015, artinya variabel independen, variabel moderasi, dan variabel kontrol berpengaruh secara simultan terhadap variabel dependen.

Berdasarkan hasil uji individu pada variabel moderasi dalam tabel 4.5, menunjukan bahwa RDI yang dimoderasi dengan variabel dewan komisaris memiliki nilai signifikan sebesar 0,060 dan nilai coefisien 0,039, memiliki arti bahwa terjadi hubungan positif dan dewan komisaris dapat mempengaruhi hubungan antara RDI dengan variabel Performance. Pada variabel RDI yang dimoderasi dengan komisaris independen memiliki nilai signifikansi sebesar 0,010 dan nilai coefisien 0,651, artinya bahwa terjadi hubungan positif dan memperkuat hubungan antara RDI dengan Performance.

Hasil penelitian penelitian yang dilakukan oleh Nahda \& Harjito (2011) menyatakan bahwa perusahaan yang telah menerapkan tata kelola yang baik 
dapat meningkatkan aktivitas pengungkapan secara luas dalam laporan tahunan. Penelitian yang dilakukan oleh Sera \& Setyaningrum (2017), dan Suhardjanto et al., (2012) menyatakan bahwa jumlah anggota dewan yang lebih besar memiliki kontrol dan pengawasan lebih baik sehingga berpengaruh positif dengan pengungkapan yang dilakukan oleh perusahaan. Sedangkan menurut Kurniawanto, et al., (2017) menyatakan bahwa komisaris independen telah menjalankan tugasnya sebagai pengawas, pemberi arahan, dan mengevaluasi pelaksanaan tata kelola perusahaan dan kebijakan strategis. Dalam penelitian yang dilakukan oleh Nuswandari (2009) menyatakan bahwa corporate governance index dapat mempengaruhi peningkatan kinerja dalam operasional perusahaan, sehingga tata kelola yang baik mampu meminimalkan terjadinya risiko dan menghasilkan tingkat profitabilitas dengan baik.

Kegiatan monitoring yang telah dilakukan oleh dewan komisaris dan komisaris independen audit telah dilakukan dengan baik sesuai dengan fungsi yang telah tertulis dalam POJK Nomor 33 Tahun 2014. Sejalan dengan teori agensi bahwa tata kelola yang baik dapat mengatasi benturan masalah kepentingan seperti manipulasi transaksi dan penyalahgunaan aset. Tata kelola perusahaan yang baik dapat meningkatkan pengawasan terhadap pelaporan risiko yang telah dilakukan oleh manajemen sekaligus menjamin adanya peningkatan kinerja perusahaan baik dalam pengelolaan aset maupun pengelolaan ekuitas dalam menghasilkan laba.

Tabel 7. Hasil Uji Sensitivitas Tanpa Variabel Moderasi

\begin{tabular}{lllllll}
\hline \multirow{2}{*}{ Variabel } & \multirow{2}{*}{ Dugaan } & \multicolumn{2}{c}{ ROA } & \multicolumn{2}{c}{ ROE } \\
\cline { 3 - 6 } & & Coef & $p$-value & Coef & $p$-value \\
\hline RDI & + & 0,076 & $0,004^{* * *}$ & 0,169 & $0,000^{* * *}$ & \\
AGE_FIRM & + & $-0,000$ & 0,311 & $-0,000$ & 0,253 & \\
SIZE & + & 0,002 & 0,321 & 0,003 & 0,217 & \\
_cons & & $-0,016$ & 0,441 & $-0,059$ & 0,354 & \\
R-Sq & & 0,064 & & & & 0,1176
\end{tabular}

Prob>Chi2 0,032 0,0001

Keterangan: ${ }^{* * *},{ }^{* * *}$ signifikansilpadalalpha 10persen, 5 persen, 1 persen

ROA diukur menggunakan total laba bersih dibagi dengan total asset; ROE diukur menggunakan total laba bersih dibagi denganltotal ekuitas; RDI (risk disclosure indeks) diukur dengan membagi total pengungkapan perusahaan dengan item pengukuran; AGE_FIRM merupakan tahun tutup buku perusahaan dikurangi tahun perusahaan terdaftar di BEI; SIZE diukur menggunakan logaritma natural total aset.

Sumber: Data Penelitian, 2020

Variabel RDI yang dimoderasi oleh komite audit menunjukan nilai signifikansi sebesar 0,444 dengan koefisien 0,022, maka memiliki arti bahwa komite audit tidak mempengaruhi pengaruh RDI terhadap PERFORMANCE. Proporsi komite audit dan pengungkapan risiko tidak memiliki pengaruh terhadap variabel kinerja perusahaan, artinya tinggi atau rendah proporsi anggota komite audit dengan latar belakang keuangan dan akuntansi tidak mempengaruhi luas pengungkapan risiko dan pengelolaan aset menjadi laba. Sejalan dengan hasil penelitian Dwitmanto, Hidayat, \& Helfina (2016), Diandono (2012), Putra \& Nuzula (2017) yang menyatakan bahwa jumlah komite audit belum dapat menjamin keefektifan fungsi komite audit dalam melakukan pengawasan terhadap profitabilitas perusahaan, pembentukan komite audit 
berdasarkan pemenuhan regulasi tata kelola dalam membentuk komite audit. Kegiatan pengawasan anggota komite audit yang efisien adalah hal yang penting dalam mencapai tingkat kesuksesan, namun terdapat kecenderungan dalam membatasi aktivitas pemantauan dalam mengimplementasikan keputusan, perusahaan yang mengejar strategi dalam berinovasi untuk mencapai profit mungkin lebih menekankan pada peran manajemen dalam mencapai strategi dan membangun peran relasional daripada peran pengawasan oleh anggota komite audit (Jermias \& Gani, 2006).

Hasil pengujian individu pada variabel RDI menunjukkan nilai signifikansi sebesar 0,000 < 0,01 dengan nilai koefisien 0,123, maka dapat diketahui bahwa variabel RDI memiliki hubungan positif dan berpengaruh signifikan terhadap PERFORMANCE. Variabel kontrol yaitu AGE_FIRM menunjukkan nilai koefisien sebesar -0,005 dengan nilai signifikansi sebesar 0,263, artinya umur perusahaan tidak berpengaruh terhadap variabel kinerja perusahaan. Variabel SIZE menunjukan nilai koefisien sebesar 0,003 dengan signifikansi sebesar 0.283, menunjukan bahwa tidak ada pengaruh antara ukuran perusahaan dengan kinerja perusahaan.

Tabel 8. Hasil Uji Sensitivitas Risk Disclosure Index dan Kinerja Perusahaan dengan Moderasi Corporate governance

\begin{tabular}{llllll}
\hline \multicolumn{1}{c}{ Variabel } & \multirow{2}{*}{ Dugaan } & \multicolumn{2}{c}{ ROA } & ROE \\
\cline { 3 - 6 } & & Coef & $p$-value & Coef & $p$-value \\
\hline RDI & + & $-0,272$ & $0,085^{*}$ & $-0,456$ & $0,048^{* *}$ \\
DK & + & $-0,008$ & $0,095^{*}$ & $-0,016$ & $0,031^{* *}$ \\
KI & + & $-0,119$ & $0,080^{*}$ & $-0,273$ & $0,012^{* *}$ \\
KA & + & $-0,011$ & 0,452 & 0,012 & 0,431 \\
RDI.DK & + & 0,026 & $0,030^{* *}$ & 0,051 & $0,003^{* * *}$ \\
RDI.KI & + & 0,456 & $0,043^{* *}$ & 0,867 & $0,09^{* *}$ \\
RDI.KA & + & 0,037 & 0,392 & 0,021 & 0,455 \\
AGE_FIRM & + & $-0,003$ & 0,289 & $-0,000$ & 0,280 \\
SIZE & + & 0,001 & 0,394 & 0,003 & 0,354 \\
_cons & & $-0,076$ & 0,301 & $-0,059$ & 0,241 \\
R-Sq & & 0,0916 & & & 0,1176 \\
Prob>Chi2 & & 0,1103 & & & 0,0002
\end{tabular}

Keterangan: ${ }^{*}, * * * * *$ signifikansijpadajalphaj10persen 5persen,1persen

ROA (Return On Assets) diukur menggunakan total laba bersih dibagi dengan total asset; ROE (return on equity) diukur menggunakan total laba bersih dibagi dengan total ekuitas; RDI (risk disclosure indeks) diukur dengan membagi total pengungkapan perusahaan dengan item pengukuran; AGE_FIRM merupakan tahun tutup buku perusahaan dikurangi tahun perusahaan terdaftar di BEI; SIZE diukur menggunakan logaritma natural total asset; DK diukur dengan jumlah keseluruhan dewan komisaris; KI diukur dengan proporsi komite independen; KA diukur dengan total keseluruhan komite audit dengan latar belakang pendidikan keuangan dibagi jumlah keseluruhan komite audit

Sumber: Data Penelitian, 2020

Hasil uji variabel RDI yang dimoderasi dengan variabel DK terhadap variabel ROE memiliki nilai koefisien sebesar 0,051 dan nilai signifikansi sebesar 0,003, artinya dewan komisaris dapat memperkuat pengaruh variabel RDI terhadap ROE. Variabel RDI yang dimoderasi dengan variabel KI memiliki nilai 
koefisien sebesar 0,867 dengan nilai signifikansi 0,09, artinya komisaris independen dapat memperkuat pengaruh RDI terhadap ROE. Variabel RDI yang dimoderasi dengan variabel KA menunjukan nilai koefisien 0.021 dengan nilai signifikansi sebesar 0,455, artinya komisaris audit tidak memiliki pengaruh terhadap hubungan RDI terhadap ROE. Berdasarkan hasil uji sensitivitas maka dapat disimpulkan bahwa pengaruh variabel moderasi yaitu dewan komisaris, komisaris independen, dan komite audit terhadap ROA dan ROE, konsisten dengan hasil regresi variabel moderasi terhadap Performance.

\section{SIMPULAN}

Berdasarkan analis data dan interpretasinya, maka diperoleh kesimpulan, pertama risk disclosure berhubungan positif dan signifikan terhadap kinerja perusahaan yang diproksikan dengan ROA dan ROE, yang memiliki arti bahwa semakin luas risk disclosure yang telah dilakukan perusahaan dapat meningkatkan kinerja perusahaan. Hal ini karena perusahaan telah memperhitungkan dengan baik risiko yang akan terjadi dimasa depan dan telah mempersiapkan antisipasi serta perlindungan diri dalam menghadapi kejadian tidak terduga yang dapat merugikan perusahaan. Kedua, Corporate governance yang diukur dengan faktor jumlah dewan komisaris dan komisaris independen memperkuat pengaruh pengungkapan risiko terhadap kinerja perusahaan, hal ini menunjukan bahwa tata kelola di Indonesia sudah menerapkan tugas dan fungsi pengawasan dengan baik, sehingga mampu menjamin luas pengungkapan secara transparan sekaligus menjamin peningkatan kinerja perusahaan. Komite audit tidak dapat mempengaruhi pengaruh antara RDI dan kinerja perusahaan.

Penelitian ini hanya menghitung beberapa item pengungkapan risiko dengan indikator GRI, sehingga perhitungan dain informasi masih sangat terbatas, diharapkan penelitian selanjutnya memperhitungkan setiap bobot item yang diungkapkan. Penelitian ini hanya menggunakan data sekunder pada Negara Indonesia, diharapkan penelitian selanjutnya dapat menambah metode pengumpulan data melakukan wawancara langsung maupun pengisian kusioner untuk mengetahui perkembangan pengungkapan risiko di Indonesia.

\section{REFERENSI}

Abdullah, M. (2018). Pengaruh pengungkapan Risiko Perusahaan terhadap Nilai Perusahaan pada Perusahaan yang Terdaftar di Indeks Saham Syariah Indonesia (ISSI). Industrial Research Workshop and National Seminar. DOI: https://doi.org/10.35313/irwns.v9i0.1094

Abraham, S., \& Cox, P. (2007). Analysing the determinants of narrative risk information in UK FTSE 100 annual reports. The British Acoounting Review 39. DOI:10.1016/j.bar.2007.06.002

Albiatar, K. (2015). Firm Characteristics, Governance Attributes and Corporate Voluntary Disclosure: Study of Jordanian Listed Companies. International Business Research Vol. 8, No.3. DOI:10.5539/ibr.v8n3p1

Amran, A., Bin, A. M., \& Hassan, B. (2009). Risk Repoting: An Exploratory Study on Risk Management Disclosure in Malaysian Annual Report. Managerial Auditing Journal. DOI: https:/ / doi.org/10.1108/02686900910919893 
Arifah, E., \& Wirajaya, I. G. (2018). Pengaruh Pengungkapan Enterprise Risk Manajemen Terhadap Nilai Perusahaan dengan Ukuran Perusahaan, Leverage, dan Profitabilitas sebagai Variable Kontrol. E-Jurnal Akuntansi Universitas Udayana, Vol $25 . \quad$ DOI: $h$ ttps:// doi.org/10.24843/EJA.2018.v25.i02.p30

Arman, A. (2012). Pengaruh Umur dan Ukuran Perusahaan, Reputasi Underwriter dan Return on Equity terhadap Tingkat Underpricing Saham di Bursa Efek Indonesia. Proceeding for Call Paper.

Atmaja, Y., Riswan, \& Tohir. (2015). Analisis Pengaruh Good Corporate governance, Ukuran Perusahaan, Leverage Perusahaan Terhadap Kinerja Keuangan Sektor Perbankan. Performance Vol.21 No.1.

Attar, D., \& Islahuddin, S. (2014). Pengaruh Penerapan Manajemen Risiko terhadap Manajemen Risiko terhadap Kinerja Keuangan Perbankan yang terdaftar di Bursa Efek Indonesia. Jurnal Akuntansi Pascasarjana Universitas Syaiah Kuala. Vol.3, No. 1. ISSN: 1829-6467

Bae, S. M., Masud, A., \& Kim, J. D. (2018). A Cross-Country Investigation of Corporate governance and Corporate Sustainability Disclosure A Signaling Theory Perspective. MDPI Sustainability. SSRN-id3221624

Claudio, L., \& Urs, W. (2010). Firm Age and Performance. MPRA Paper No.26450. https://mpra.ub.uni-muenchen.de/26450/1/age_performance.pdf

Darmawi, H. (2014). Manajemen Risiko. Jakarta: Bumi Aksara.

Dwitmanto, Hidayat, \& Helfina, R. (2016). Pengaruh Mekanisme Good Corporate governance terhadap Profitabilitas Perusahaan. Jurnal Administrasi Bisnis

Irma, A. (2019). Pengaruh Komisaris, Komite Audit, Stuktur Kepemilikan, Size, Leverage terhadap Kinerja Perusahan Properto, Perumahan dan Konstruksi 2013-2017. Jurnal Ilmu Manajemen Volume 7 Nomor 3. E-ISSN: 2549-192X

Iswara, P. (2014). Corporate governance dan Kinerja Perusahaan. Jurnal Akuntansi, Ekonomi, dan Manajemen Bisnis Vol.2, No.2. DOI: https://doi.org/10.30871/jaemb.v2i2.147

Jensen, M., \& Meckling, W. (1976). Theory of the firm; Managerial Behavior Agency Cost and Ownership Structure. Journal of Financial Economics, 307210. https://doi.org/10.1016/0304-405X(76)90026-X

Jermias, J., \& Gani, L. (2006). Investigating the Effect of Board Independence on Performance Across Different Strategies. The International Journal of Accounting 41. https:/ / doi.org/10.1016/j.intacc.2006.07.009

Karewur, S. (2016). Deteksi Analisis Efisiensi Modal Kerja dengan Pendekatan Teori Sinyal. Jurnal Perilaku dan Strategi Bisnis, Vol. 4, No.1. DOI:10.26486/jpsb.v4i1.446

Kasmir. (2012). Analisis Laporan Keuangan.

Keputusan Ketua Bapepam-LK Nomor Kep-431/BL/2012, tentang Penyampaian Laporan Tahunan Emiten atau Perusahaan Publik Berdasarkan Keputusan Ketua Badan Pengawan Pasar Modal dan Lembaga Keuangan.

Kocmanova, A., \& Simberova, I. (2012). Modelling of Corporate governance Performance Indicators. Inzinerine Ekonomika-Engineering Economics. DOI: https:// doi.org/10.5755/j01.ee.23.5.2865 
Linsley, P., \& Shrives, P. (2014). Examining risk reporting in UK public companies. The Journal of Risk Finance, Vol 6 Iss 4. DOI:10.1108/15265940510613633

Luthfiana, H. (2015). Warga Karawang Protes Limbah Pabrik Kertas Sinar Mas. Karawang: Tempo.co.

Muslih, M., \& Mulyaningtyas, C. (2019). Pengaruh Corporate governance, Kompetisi, dan Karakteristik Perusahaan Terhadap Pengungkapan Risiko Perusahaan . Jurnal Aset (Akutansi Riset), 11 (1).

Nahar, S., Jubb, C., \& Azim, M. (2016). Risk Governance and Performance: A Developing County Perpective. Managerial Auditing Journal, 31(3). DOI:10.1108/MAJ-02-2015-1158

Nahda, K., \& Harjito, D. (2011). Pengaruh CSR terhadap Nilai Perushaaan dengan Corporate governance sebagai Variabel Moderasi. SIASAT BISNIS Vol 15, No 1. https://journal.uii.ac.id/JSB/article/view/3188

Nuswandari. (2009). Pengaruh Corporate governance Perception Index Terhadap Kinerja Perusahaan Pada Perusahaan Yang Terdaftar Di Bursa Efek Jakarta. Jurnal Bisnis Dan Ekonomi (Jbe). https://www.unisbank.ac.id/ojs/index.php/fe3/article/view/316

Onasis, K., \& Robin. (2016). Pengaruh Tata Kelola Perusahaan terhadap Nilai Perusahaan pada Perusahaan Sektor Keuangan yang Terdaftar di BEI. Bina Ekonomi Vol 20, No $1 . \quad$ DOI: https:// doi.org/10.26593/be.v20i1.1893.1-22

Pamudji, S., \& Trihartati, A. (2010). Pengaruh Independensi dan Efektivitas Komite Audit terhadap Manajemen Laba. Jurnal Dinamika Akuntansi Vo.2, No.2, 22. DOI: https://doi.org/10.15294/jda.v2i1.1924

Peraturan Jasa Otoritas Keuangan (POJK) Nomor 33/POJK 04/2014, tentang Direksi dan Dewan Komisaris Emiten atau Perusahaan publik.

PSAK 60 (Revisi 2016) tentang Instrumen Keuangan: Pengungkapan.

Puteri, P. (2013). Karakteristik Good Corporate governance dan Kinerja Perusahaan Manufaktur. E-Jurnal Akuntansi Universitas Udayan, Vol.2 No.3. DOI: https:// doi.org/10.24843/EJA.2021.v31.i04

Putra, B. (2015). Pengaruh Dewan Komisaris, Proporsi Komisaris Independen, terhadap Kinerja Perushaaan. Jurnal Manajemen Teori dan terapan, Tahun 8, No2. http://dx.doi.org/10.20473/jmtt.v8i2.2724

Ruwita, C. (2012). Analisis Pengaruh Karakteristik Perusahaan dan Corporate governance terhadap Pengungkapan Risiko Perusahaan. Skripsi.

Saemargani, F., \& Mustikawati, I. (2015). Pengaruh Ukuran Perusahaan, Umur Perusahaan, Profitabilitas, Solvabilitas, Ukuran KAP, dan Opini Auditor terhadap Audit Delay. Nominal September. DOI: https:// doi.org/10.21831/nominal.v4i2.7996

Sakti, Y. (2017). Pengaruh Pengungkapan CSR terhadap Kinerja Perushaaan Sektor Pertambangan yang Terdaftar di BEI. Jurnal Akuntansi dan Teknologi Informasi (JATI) Vol.11 , 3. DOI: https:// doi.org/10.24123/jati.v11i1.270

Saskara, \& Budiasih. (2018). Pengaruh Leverage dan Profitabilitas pada Pengungkapan Manajemen Risiko. E-Jurnal Akuntansi Universitas Udayana Vol.24.3, 2005. DOI: https:/ / doi.org/10.24843/EJA.2018.v24.i03.p13 
Saufanny, A., \& Khomsatun, S. (2017). Corporate governance dan Pengungkapan Manajemen Risiko Bank Syariah di Indonesia. Jurnal Akuntansi dan Keuangan Islam Vol 5 (1). E-ISSN: 2549-3876

Sianipar, N., Hapsari, D., \& Boediono, E. (2018). Pengaruh Kepemilikan Institusional, Kepemilikan Manajerial, Komisasis Independen tehradap Return On Asset (ROA). e-Proceeding of Management: Vol.5, No.1, 648.

Siek, R. (2015). Studi Pengaruh Tata Kelola Perusahaan terhadap Nilai Perusahaan. Calyptra: Jurnal Ilmiah Mahasiswa Universitas Surabaya Vol. 4 No.2. https://journal.ubaya.ac.id/index.php/jimus/article/view/2167

Sudiyatno, B., \& Puspitasari, E. (2010). Tobin's q dan Altman Z-Score sebagai Indikator Pengukuran Kinerja Perusahaan. Kajian Akuntansi. Vol 2, No.9.

Suhardjanto, D., \& Dewi, A. (2011). Pengungkapan Risiko Finansial dan Tata Kelola Perusahaan: Studi Empiris Perbankan Indonesia. Jurnal Keuangan dan Perbankan, Vol. 15, No.1, 106-108. http://jurnal.unmer.ac.id/index.php/jkdp/article/view/1005

Suhardjanto, D., \& Rahmawati, E. (2012). Peran Board of Directors dalam Operational Risk Disclosure studi Empiris Perbankan Indonesia. Trikonomika, Vol.11, No.1. ISSN 1411-514X

Supriyadi, A., \& Setyorini, C. (2020). Pengaruh Pengungkapan Manajemen Risiko Terhadap Nilai Perusahaan Melalui Kinerja Keuangan di Industri Perbankan Indonesia. Owner: Riset dan Jurnal Akuntansi, Vol 4 No 2. DOI: 10.33395/owner.v4i2.257

Susilatri, Agusti, R., \& Indriani, D. (2011). Pengaruh Leverage, profitabilitas, Size, Umur Perusahaan, dan Ukuran Dewan Komisaris terhadap Pengungkapan Tanggung Jawab Sosial Perusahaan. Pekbis Jurnal, Vol. 3, No.1.

Syaifurakhman, B., \& Laksito, H. (2016). Faktor - faktor yang Memperngaruhi Pengungkapan Risiko. Diponegoro Journal of Accounting, Vol.5 No.4. ISSN : 2337-3806

UNCTAD. (2017). The Role of disclosure in risk assessment and enchacing the usefulness of corporate reporting in decision-making. United National Conference on Trade and Development, (pp. 1-6). United National.

Utami, C., \& Ratmono, D. (2018). Pengaruh Pengungkapan Rsiko Terhadap Biaya Modal Ekuitas dan Kinerja Bank. Diponegoro Journal Of Accounting Volume 7, Nomor 4. ISSN : 2337-3806

Wardhany, D., Sri, H., \& Wiyono, G. (2019). Pengaruh Profitabilitas, Leverage, dan Ukuran Perusahaan Terhadap Nilai Perusahaan . Ensiklopedia of Journal Vol.2 No.1. DOI: https://doi.org/10.33559/eoj.v2i1.388

Yunifa, L., \& Juliarto, A. (2017). Analisis Pengaruh Karakteristik Perusahaan terhadap Tingkat Pengungkapan Risiko pada Perusahaan Manufaktur. Diponegoro Journal of Accounting, Vol.6, No.3. ISSN : 2337-3806 